\title{
Antioxidant, Anti-Proliferative and Bronchodilatory Activities Of Euphorbia Hirta Extracts
}

\author{
Chen. Y. $\mathrm{S}^{1 *}$ \& $\operatorname{Er}$ H. M. ${ }^{2}$
}

${ }^{12}$ Human Biology Section and ${ }^{2}$ School of Pharmacy, International Medical University, Kuala Lumpur, Malaysia.

*yusui_chen@imu.edu.my (corresponding author)

Received on $24^{\text {th }}$ November 2009, accepted in revised form 18th March 2010.

ABSTRACT Euphorbia hirta is a plant commonly found in wild lands in tropical countries. It has various medicinal uses such as for conjunctivitis, ulcerated cornea, asthma, bronchitis, upper respiratory catarrh etc. In this study, crude n-hexane, chloroform, methanol and water extracts of the plant were screened for their antioxidant activities using an improved 2, 2'-azinobis-3-ethylbenzothiazoline-6-sulfonic acid (ABTS) radical cation decolorisation assay method. The methanol and water extracts showed comparable antioxidant activities to those of green and black teas. On the other hand, the chloroform and n-hexane extracts did not show significant antioxidant activities. The extracts were also screened for anti-proliferative acitivities against normal mouse fibroblast cells (NIH/3T3). Results indicated that the methanol and chloroform extracts were less anti-proliferative than the water and hexane extracts. The effect of Euphorbia hirta aqueous extract on guinea pig trachea was studied. The water extract alone did not have any effect on the guinea pig trachea but it showed partial inhibition on the histamine induced tracheal smooth muscles contractions. Therefore, further studies may focus on water extract as it showed considerable antioxidant activity and partial inhibitory effect on histamine induced tracheal smooth muscle contractions.

(Keywords: Antioxidant activity; Bronchodilation; Anti-proliferative activity; Euphorbia hirta; Plant extracts.)

\section{INTRODUCTION}

Euphorbia hirta is also known as Euphorbia pilulifera comes from the euphorbiaceae (spurge family). E. hirta is native to Africa and Australia where it is known as Australian asthma herb and Queensland asthma weed ${ }^{1}$ (Johnson et al., 1998). This plant is also very commonly found in tropical countries such as Malaysia. Flower extracts of $E$. hirta have been found to be anti-bacterial and noncytotoxic and water and ethanol leaf extracts function as a diuretic ${ }^{2}$ (Vijaya et al., 1995). Aqueous leaf extracts had been shown to decrease gastrointestinal motility in rats and mice ${ }^{3}$ (Hore et al., 2006) and whole plant extracts shown to have chemosuppressive activities on parasitaemia in mice infected with $P$. berghei berghei ${ }^{4}$ (Tona et al., 1999). This study aims to investigate the antioxidant and cycotoxic properties of E. hirta against normal cells as it has been widely used in traditional medicine for decades. Besides this, the bronchodilatory property was also studied as it had been used for asthma, bronchitis and upper respiratory catarrh ${ }^{3,5}$ (Hore et al., 2006; Burkill; 1966).

\section{MATERIALS AND METHODS}

\section{Preparation of extracts}

Euphorbia hirta used in this study had been authenticated by Roy Vickery, Department of Botany, The Natural History Museum, London. The whole plant material was washed and dried at $40^{\circ} \mathrm{C}$. The dried plant material $(8 \mathrm{~g})$ was powdered and extracted sequentially with $200 \mathrm{~mL}$ each of $\mathrm{n}$-hexane, chloroform, methanol and water using a soxhlet extractor. The solvents in the extracts were removed under reduced pressure using a rotary evaporator until consistent extract weights were obtained. The water extract was further freeze-dried to obtain a consistent weight. The yields of the n-hexane, chloroform, methanol and water extracts were $2 \%$, $1 \%, 7 \%$ and $16 \%$, respectively, from the dried material.

\section{Antioxidant activity}

The antioxidant activities of the extracts were assessed using an improved ABTS radical cation decolorisation assay ${ }^{6}(\mathrm{Re}$ et al., 1999).

ABTS (2,2'-azinobis(3-ethylbenzothiazoline-6sulfonic acid) $(7.0 \mathrm{mM}, 715 \mu \mathrm{L})$ and potassium persulfate $(8.6 \mathrm{mM}, 285 \mu \mathrm{L})$ were mixed and allowed 
to react in the dark at room temperature for $16 \mathrm{~h}$ to form ABTS ${ }^{\bullet+}$ radical. The ABTS ${ }^{\bullet+}$ solution was diluted with phosphate buffered saline (PBS) at $\mathrm{pH}$ 7.4 , to an absorbance of $0.70( \pm 0.20)$ measured at $734 \mathrm{~nm}$. A $10 \mu \mathrm{L}$ aliquot of each extract solution was added to $990 \mu \mathrm{L}$ of the diluted ABTS ${ }^{\bullet+}$ solution and the absorbance of the resulting solution at 734 $\mathrm{nm}$ was recorded at every minute after mixing up to 6 minutes. The final concentrations of the water and methanol extracts in the reaction mixture ranged between 1.25 to $10 \mu \mathrm{g} / \mathrm{mL}$. For the chloroform and hexane extracts, the assays were carried out at 10 $\mu \mathrm{g} / \mathrm{mL}$ (precipitation occurred at higher concentrations, whereas the response was insignificant at lower concentrations). The effects of Trolox standards (final concentration 2.5 to $25 \mu \mathrm{M}$ ) were also determined in the assay. All determinations were carried out in triplicates. Appropriate solvent blank was included in each assay. The percentage inhibition of the absorbance at 734 $\mathrm{nm}$ was determined. The antioxidant capacity of each extract was determined at 6 minutes and expressed in Trolox equivalents (TE)/g dry matter (using the concentration-response curve of Trolox determined at 6 minutes).

\section{Anti-proliferative activity against normal mouse fibroblast cells (NIH/3T3)}

The assay.is based on the ability of viable, metabolic active cells to cleave yellow tetrazolium salt, MTT (3-(4,5-dimethylthiazol-2-yl)-2,5-diphenyl tetrazolium bromide) to form a blue formazan product using the mitochondrial dehydrogenase. Dead cells or tissue culture medium do not participate in the reduction. The solubilised formazan product is analysed spectrophotometrically and the percentage of cell survival can then be quantified.

The weighed extracts were dissolved in dimethyl sulfoxide (DMSO) and diluted to various concentrations with DMEM media containing $10 \%$ foetal bovine serum. These were filtered through $0.22 \mu \mathrm{m}$ membrane filters. The final concentration of DMSO in each diluted extract solution was not more than $0.3 \%(\mathrm{v} / \mathrm{v})$ (it has previously been shown that cell growth is not affected in media containing not more than $0.3 \%(\mathrm{v} / \mathrm{v})$ DMSO). The diluted extract solutions were added to the respective wells of 96well flat-bottomed tissue culture plates (Nunc, Denmark) containing NIH/3T3 cells at $1 \times 10^{4}$ cells/well. The final concentrations of the extracts in each assay ranged from 6.25 to $300 \mu \mathrm{g} / \mathrm{mL}$. Triplicates were performed for each extract concentration in each assay and the assay was repeated. Wells containing cells only in culture medium containing not more than $0.3 \%(\mathrm{v} / \mathrm{v})$ DMSO were included as the negative controls. The plates were incubated in a humidified $5 \% \mathrm{CO}_{2}$ incubator at $37^{\circ} \mathrm{C}$ for 72 hours. At the end of the 72 hours incubation period, $20 \mu \mathrm{L}$ of MTT $(5 \mathrm{mg} / \mathrm{mL}$ in PBS) was added to each well and the plates were further incubated at $37^{\circ} \mathrm{C} 5 \% \mathrm{CO}_{2}$ for 4 hours. The media in each well was then discarded and formazan crystals formed were dissolved with $80 \mu \mathrm{L}$ dimethyl sulfoxide. The absorbance at $550 \mathrm{~nm}$ in each well was obtained and the percentage of cell survival was calculated.

\section{Bronchodilatory activity}

The guinea pigs were housed in the animal holding facility where food and water were given ad libitum. All experimental procedures were approved by the ethics committee of International Medical University. Before the removal of tracheas, the guinea pigs were euthanised using chloroform. The tracheas were isolated from male guinea pigs weighing about $400 \mathrm{~g}$. Tracheas were cut spirally into two strips $20 \mathrm{~mm}$ long and $4 \mathrm{~mm}$ wide. The tracheal strips were mounted vertically in a $10 \mathrm{~mL}$ organ bath containing Krebs buffer aerated with a mixture of $95 \% \mathrm{O}_{2}$ and $5 \% \mathrm{CO}_{2}$ at $37^{\circ} \mathrm{C}$. The composition of Krebs buffer was as follow (in $\mathrm{mM}$ ): $\mathrm{NaCl} 118, \mathrm{KCl} 4.7, \mathrm{CaCl} \mathrm{2.4}$, $\mathrm{MgSO}_{4} 1.2, \mathrm{KH}_{2} \mathrm{PO}_{4} 1.2, \mathrm{NaHCO}_{3} 25$, and glucose 11. Changes in isometric tension were recorded with Powerlab ${ }^{\mathrm{TM}}$. Before each experiment the strips were subjected to a tension of $2 \mathrm{~g}$ for about 2 hours until a stable baseline tension was obtained. Dose response curves for histamine $\left(10^{-7}\right.$ to $\left.10^{-4} \mathrm{M}\right)$ were obtained in the absence or presence of water extracts $(1,5,10$ and $20 \mu \mathrm{g} / \mathrm{m})$, methanol extracts $(20 \mu \mathrm{ug} / \mathrm{mL})$, chloroform extracts $(27 \mathrm{ug} / \mathrm{mL})$, and n-hexane extracts $(28 \mathrm{ug} / \mathrm{mL})$. Dried solvent extracts were suspended in DMSO before adding into organ bath. All drug concentrations indicated are expressed as the final concentrations in the organ bath.

Student t-test was used for statistical analysis.

\section{Antioxidant activity}

The graphs of the percentage inhibition of absorbance at $734 \mathrm{~nm}$ versus time for the Trolox standards and extracts are shown in Figures 1(a) - 1(d). The concentration-response curve for the Trolox standards, water and methanol extracts are shown in Figures 2(a) - 2(c). The antioxidant capacity of each of the water and methanol extracts was determined by dividing the gradient of the concentrationresponse curve of the extract by the gradient of the plot for Trolox. The antioxidant capacities of the water and methanol extracts are $1437 \mu \mathrm{mol}$ Trolox Equivalent/g dry matter and $854 \mu \mathrm{mol}$ Trolox. 


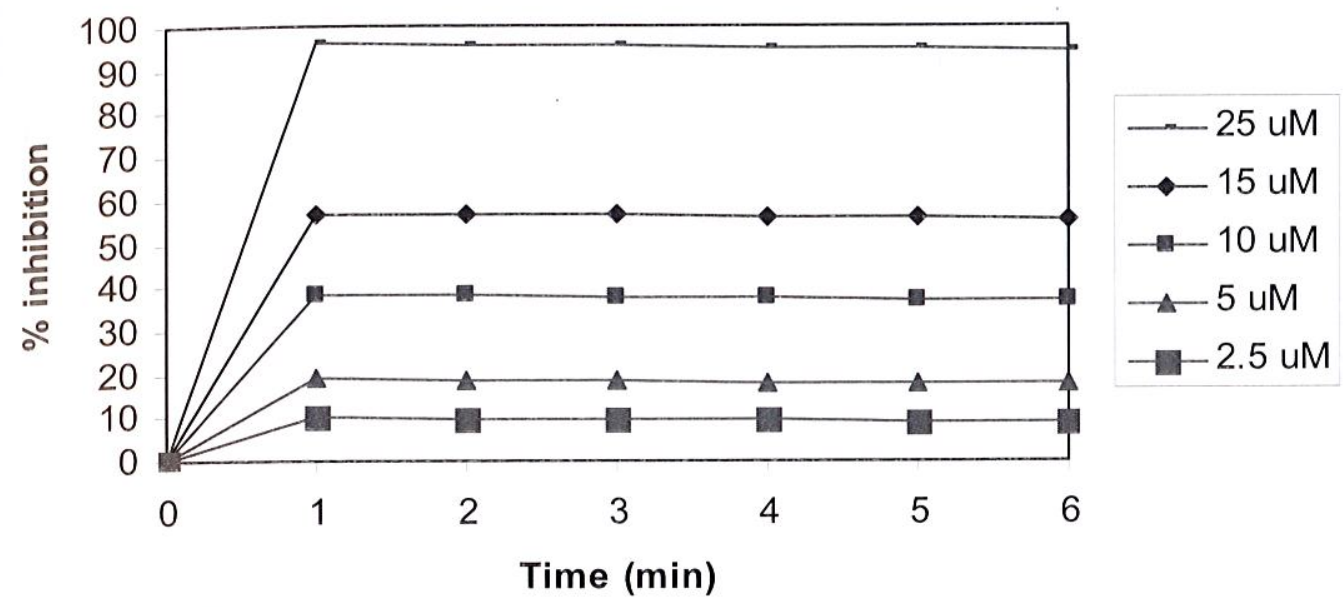

Figure 1(a): Time-dependent study of the percentage inhibition of the absorbance of ABTS $^{+}$by various concentrations of Trolox.

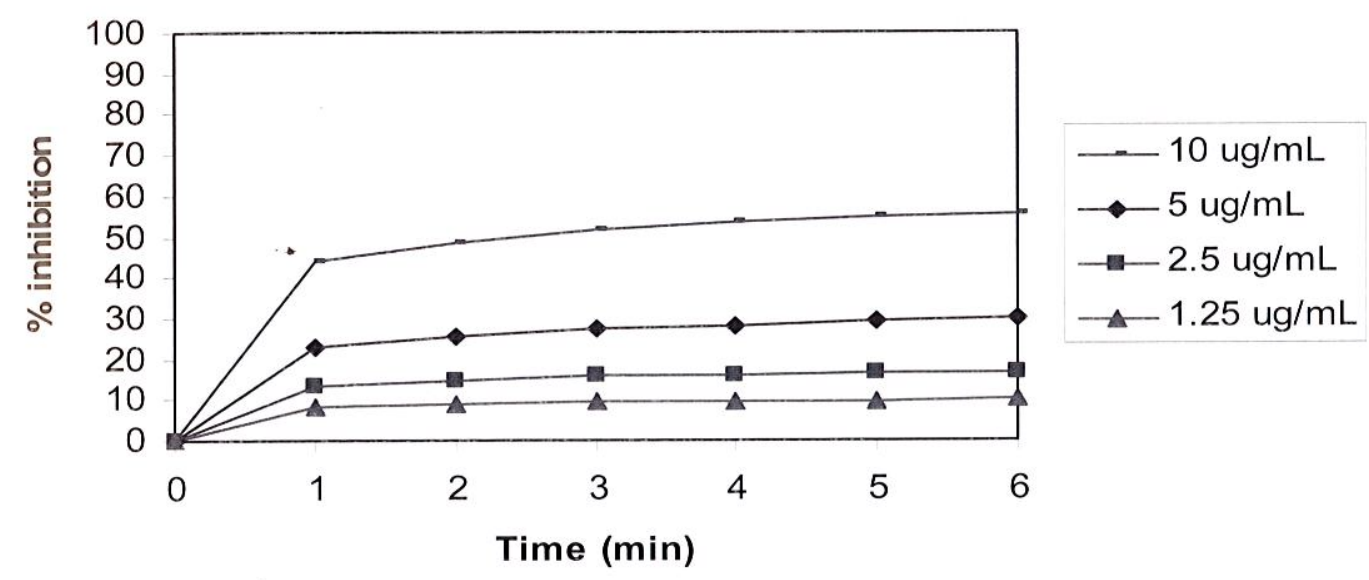

Figure 1(b): Time-dependent study of the percentage inhibition of the absorbance of ABTS $^{+}$by various concentrations of the aqueous extract of Euphorbia hirta.

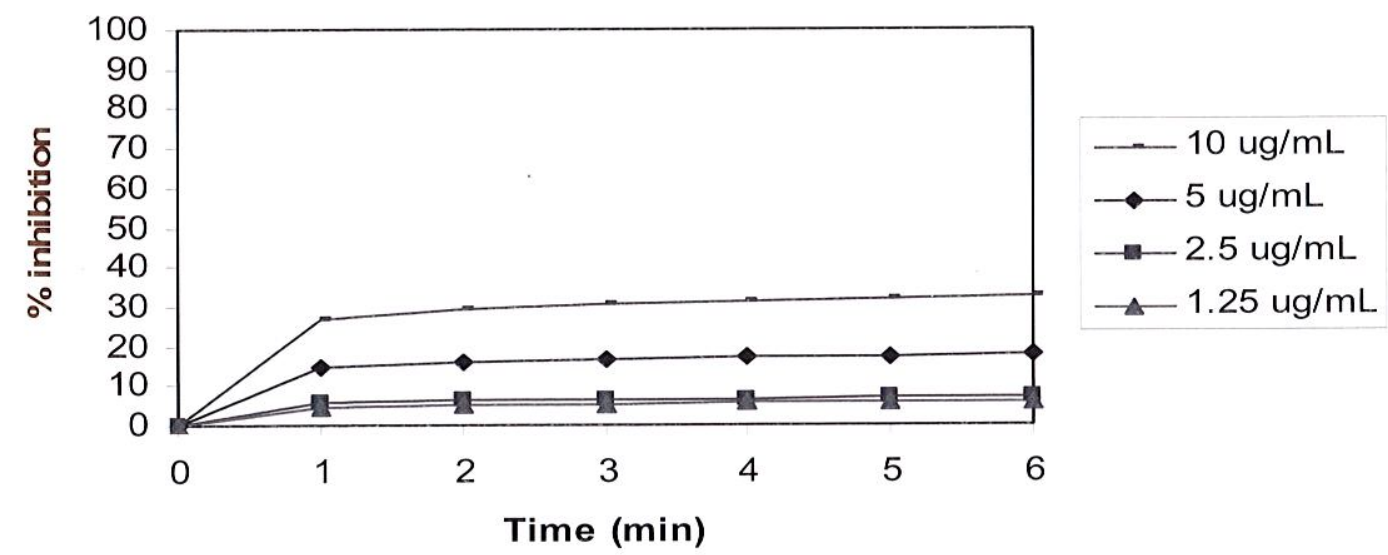

Figure 1(c): Time-dependent study of the percentage inhibition of the absorbance of $\mathrm{ABTS}^{+}$by various concentrations of the methanol extract of Euphorbia hirta. 


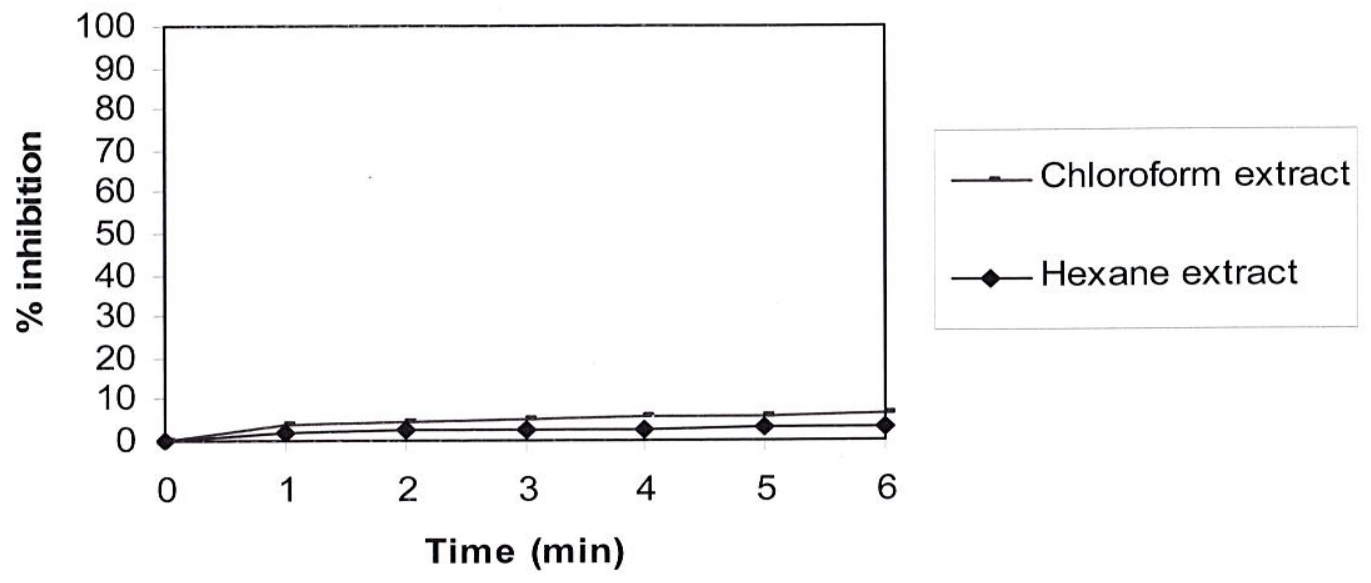

Figure 1(d): Time-dependent study of the percentage inhibition of the absorbance of $\mathrm{ABTS}^{+}$by $10 \mu \mathrm{g} / \mathrm{mL}$ of the chloroform and hexane extracts of Euphorbia hirta.

Equivalent/g dry matter, respectively. Meanwhile, the chloroform and $\mathrm{n}$-hexane extracts at $10 \mu \mathrm{g} / \mathrm{mL}$ showed less than $10 \%$ inhibition of absorbance at 734 $\mathrm{nm}$, indicating that their anti-oxidant activities were insignificant.

Anti-proliferative activity against normal mouse fibroblast cells

The dose-response curves for the extracts are shown in Figures 3(a) - 3(d). The $\mathrm{IC}_{50}$ values for all extracts against normal mouse fibroblast cells are above 200 $\mu \mathrm{g} / \mathrm{mL}$, with the methanol and chloroform extracts being less anti-proliferative than the water and hexane extracts. According to the National Cancer Institute, a crude extract should have an $\mathrm{IC}_{50}$ of less than $20 \mu \mathrm{g} / \mathrm{mL}$ for it to be considered cytotoxic ${ }^{7}$ (Geran et al., 1972). Therefore, these extracts are considered to be non-cytotoxic against normal mouse fibroblast cells.

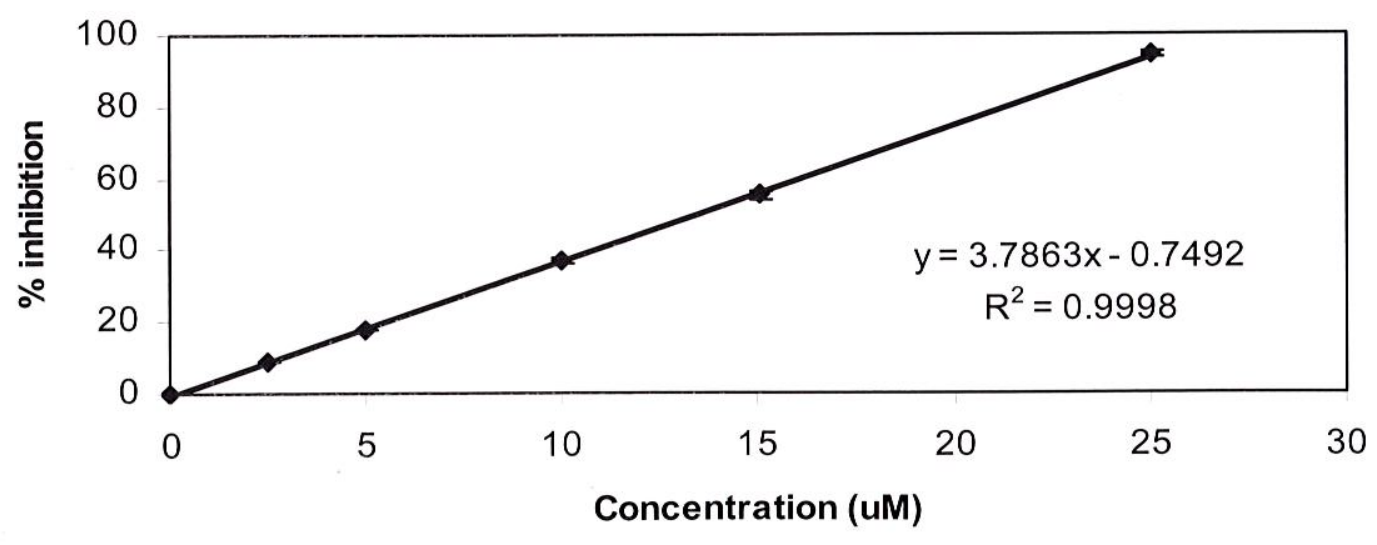

Figure 2(a): Concentration-response curve for the percentage inhibition of the absorbance of $\mathrm{ABTS}^{+}$as a function of concentration of standard Trolox solution. 


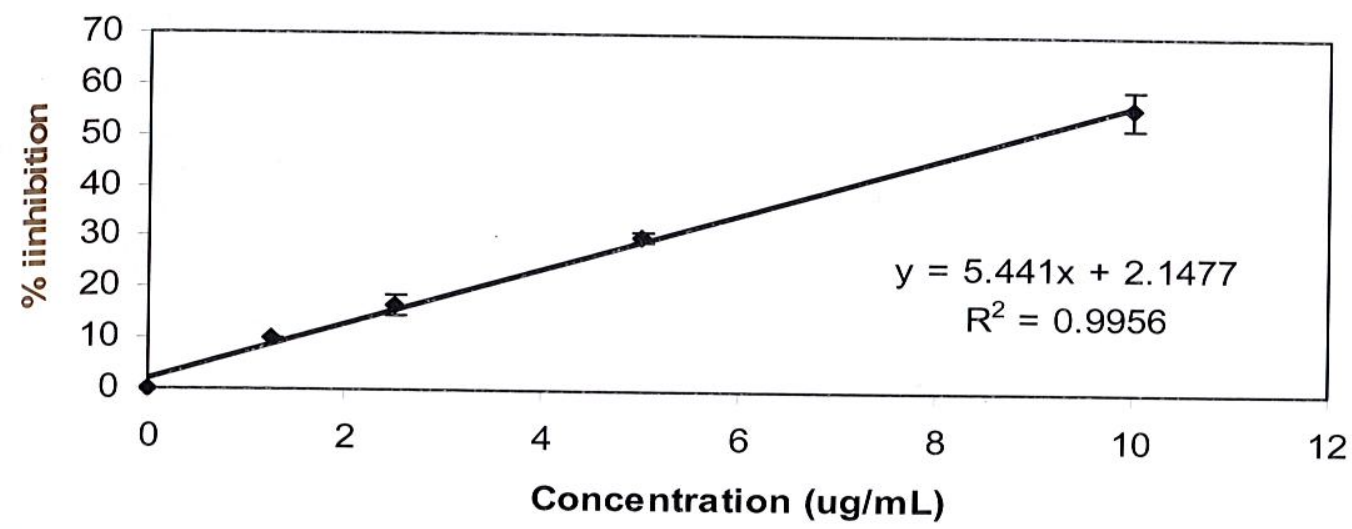

$\mathrm{L}$ of the

ove 200 extracts ter and Cancer 0 of less otoxic $^{7}$ acts are 1 mouse

Figure 2(b): Concentration-response curve for the percentage inhibition of the absorbance of $\mathrm{ABTS}^{+}$as a function of concentration of the aqueous extract of Euphorbia hirta.

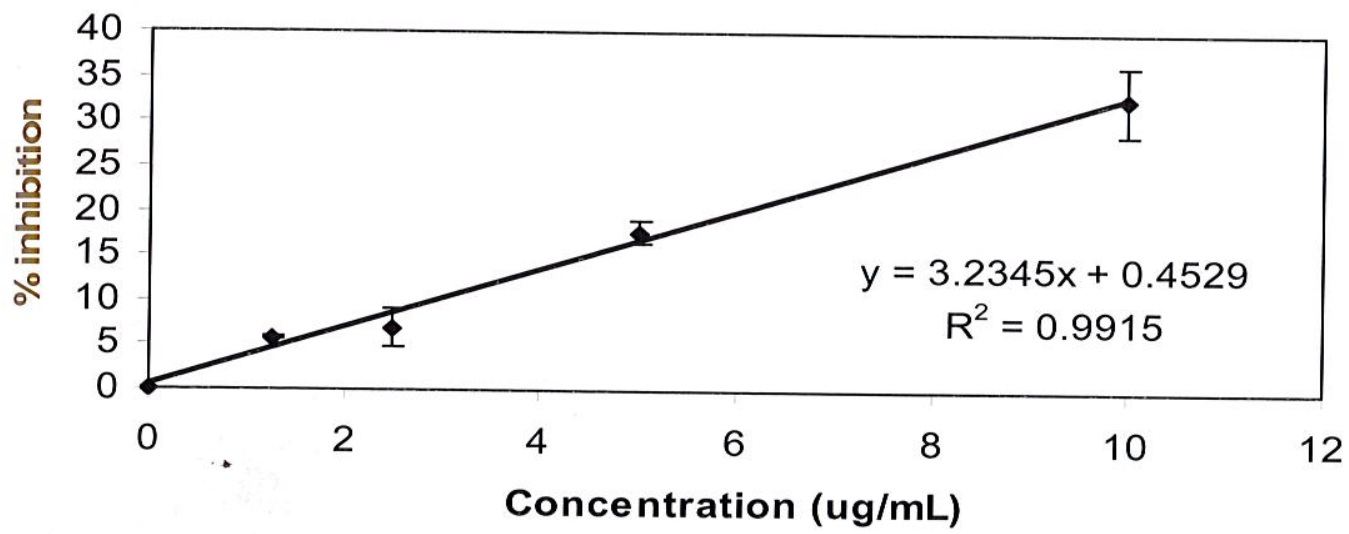

Figure 2(c): Concentration-response curve for the percentage inhibition of the absorbance of $\mathrm{ABTS}^{+}$as a function of concentration of the methanol extract of Euphorbia hirta.

\section{Bronchodilatory activity}

There was significant inhibitory effect of water extract on histamine induced tracheal contraction (Figure 4). The minimum effective concentration of the water extract found was $5 \mu \mathrm{g} / \mathrm{mL}$ and there was no greater inhibition at 10 and $20 \mu \mathrm{g} / \mathrm{mL}$. The $\mathrm{EC}_{50}$ value for histamine was $1.7 \times 10^{-6} \mathrm{M}(\mathrm{n}=5)$ and the $\mathrm{EC}_{50}$ values for histamine in the presence of $5 \mu \mathrm{g} / \mathrm{mL}$ and $10 \mu \mathrm{g} / \mathrm{mL}$ water extracts were and $1.6 \times 10^{-5} \mathrm{M}$ $(n=4)$ and $6.2 \times 10^{-6} \mathrm{M}(\mathrm{n}=5)$ respectively. The results showed that the water extracts were able to shift the dose-response curve parallelly to the right. The $\mathrm{EC}_{50}$ values of histamine in the presence of water extract were significantly larger than that of histamine alone $(p<0.05)$. No inhibitory effect was observed at 1 $\mu \mathrm{g} / \mathrm{mL}$ water extract (data not shown). Water extract alone did not cause relaxation in tracheas. All the other solvent extracts (chloroform extract, $27 \mu \mathrm{g} / \mathrm{mL}$; hexane extract, $28 \mu \mathrm{g} / \mathrm{mL}$ and methanol extract, 20 $\mu \mathrm{g} / \mathrm{mL}$ ) tested showed no effect either on the tracheas alone or on histamine induced tracheal contraction.

\section{DISCUSSIONS AND CONCLUSION}

The water and methanol extracts of Euphorbia hirta showed antioxidant capacity comparable to those of commercial green and black teas with antioxidant capacity ranging from $235 \mu \mathrm{mol}$ Trolox Equivalent/g dry matter to $1526 \mu \mathrm{mol}$ Trolox Equivalent/g dry matter ${ }^{8}$ (Prior and Cao, 1999). This may be attributed to the presence of one of the active constitutents in the plant, quercetin ${ }^{9}$ (Tona et al., 2004). Quercetin is a flavonoid that has been shown to have antioxidant activity. The lack of cytotoxic activity of the extracts against normal mouse fibroblast cells provides some assurance for the safety of the plant which is commonly used by traditional medicine practitioners. However, further 
in vivo experiments are needed to ascertain its toxicological effects.

The inhibitory action of the water extracts of Euphorbia hirta on histamine induced tracheal contraction provides evidence to its use as a traditional medicine to treat asthmatic patients who are hypersensitive to bronchoconstrictor agents such as histamine and $\mathrm{PGF}_{2 \alpha}$. The underlying mechanism may be due to its anti-inflammatory properties reported by Lanhers ${ }^{10}(1990)$. This can be studied by investigating the bonchodilatory effect of water extracts of Euphorbia hirta on tracheas pretreated with indomethacin. Moreover, quercetin in Euphorbia hirta may play a role as quercetin has been shown to inhibit histamine release from basophils ${ }^{11}$ (Ogasawara et al., 1986).

Further studies should focus on water extract as it showed considerable antioxidant activity and partial inhibitory effect on histamine induced tracheal smooth muscle contractions.

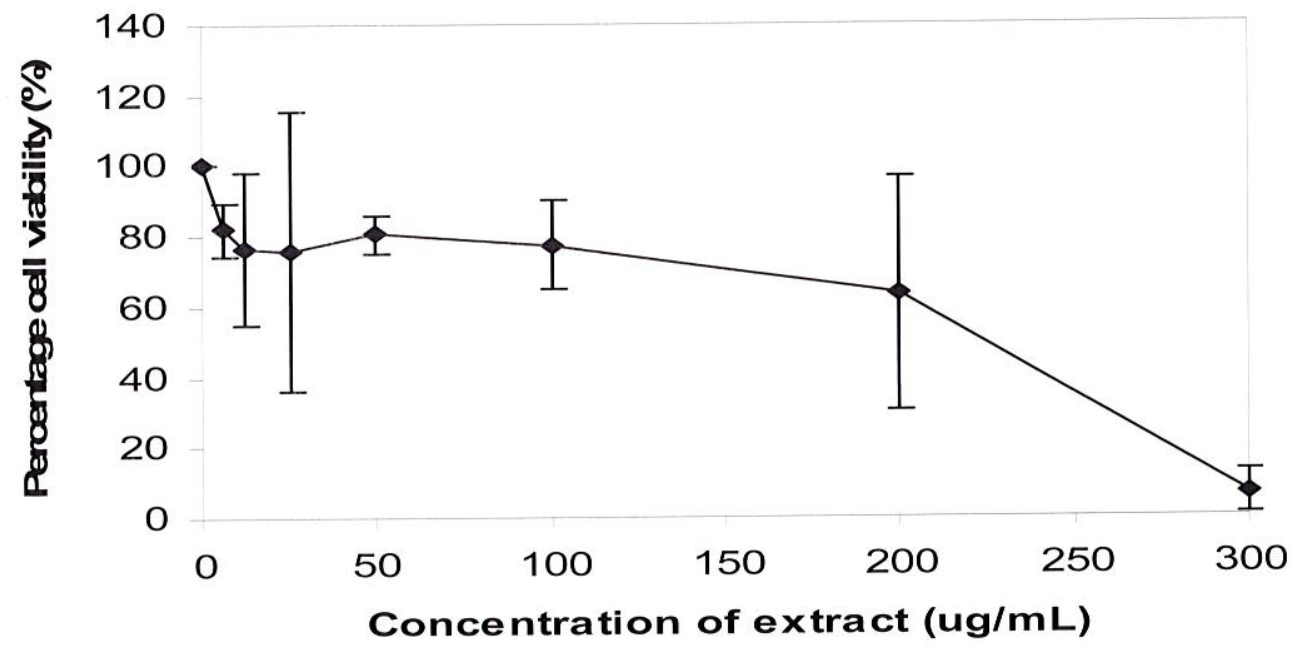

Figure 3(a): Percentage of cell viability of NIH/3T3 cells cultured in media containing 10\% FBS in the presence of varying concentrations of the aqueous extract of Euphorbia hirta.

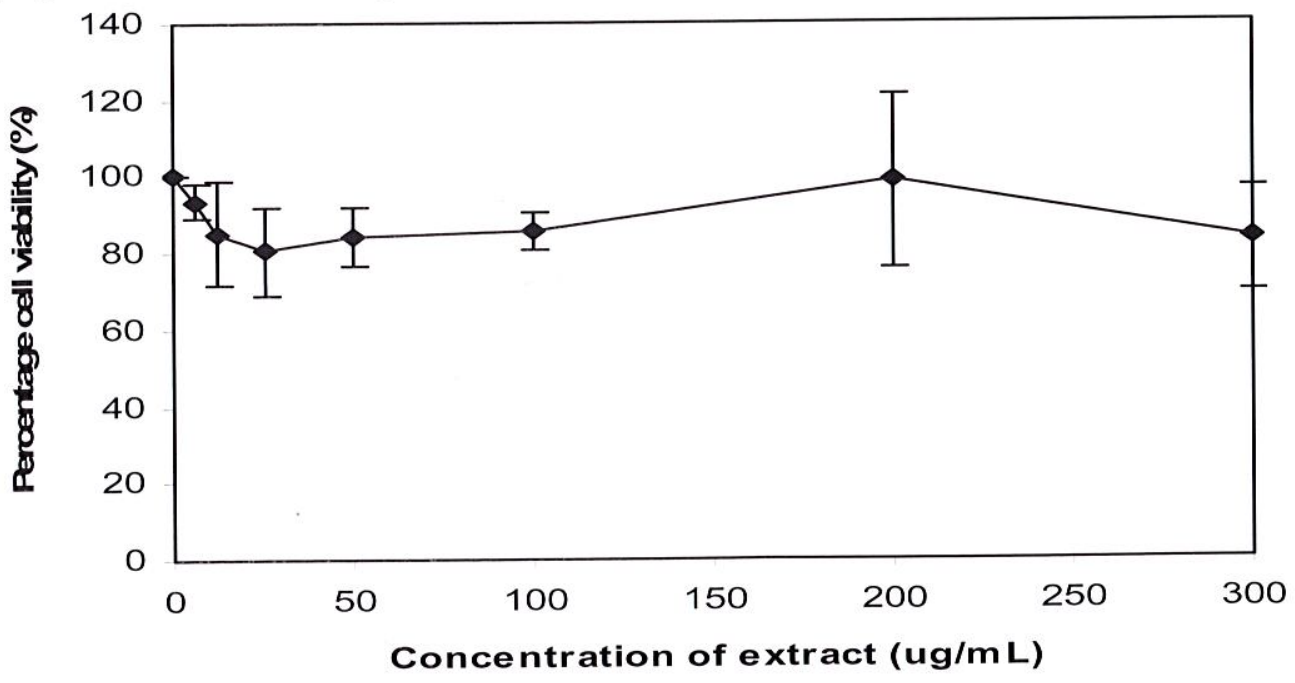

Figure 3(b): Percentage of cell viability of NIH/3T3 cells cultured in media containing 10\% FBS in the presence of varying concentrations of the methanol extract of Euphorbia hirta. 


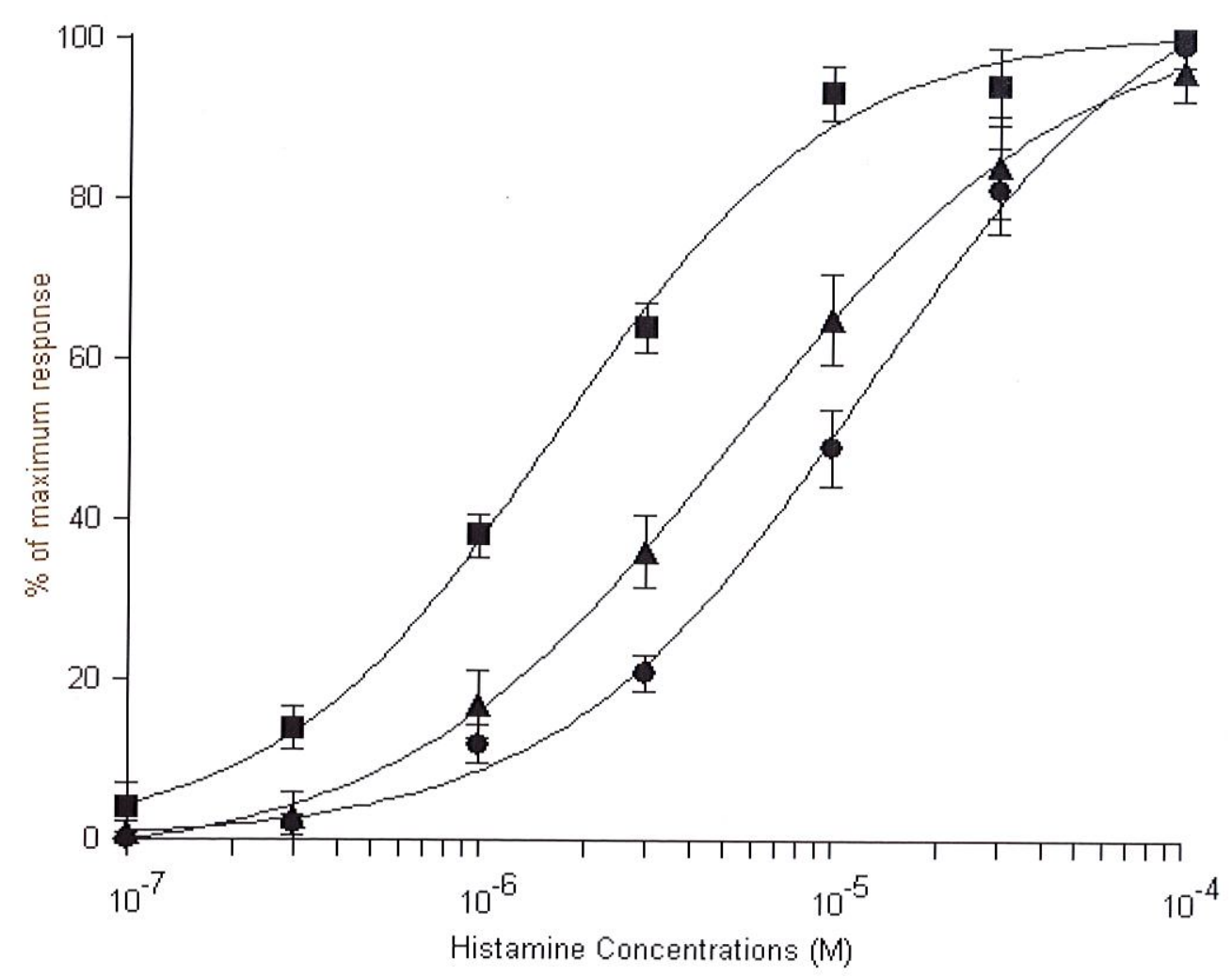

Figure 3(c): Percentage of cell viability of NIH/3T3 cells cultured in media containing $10 \% \mathrm{FBS}$ in the presence of varying concentrations of the chloroform extract of Euphorbia hirta.

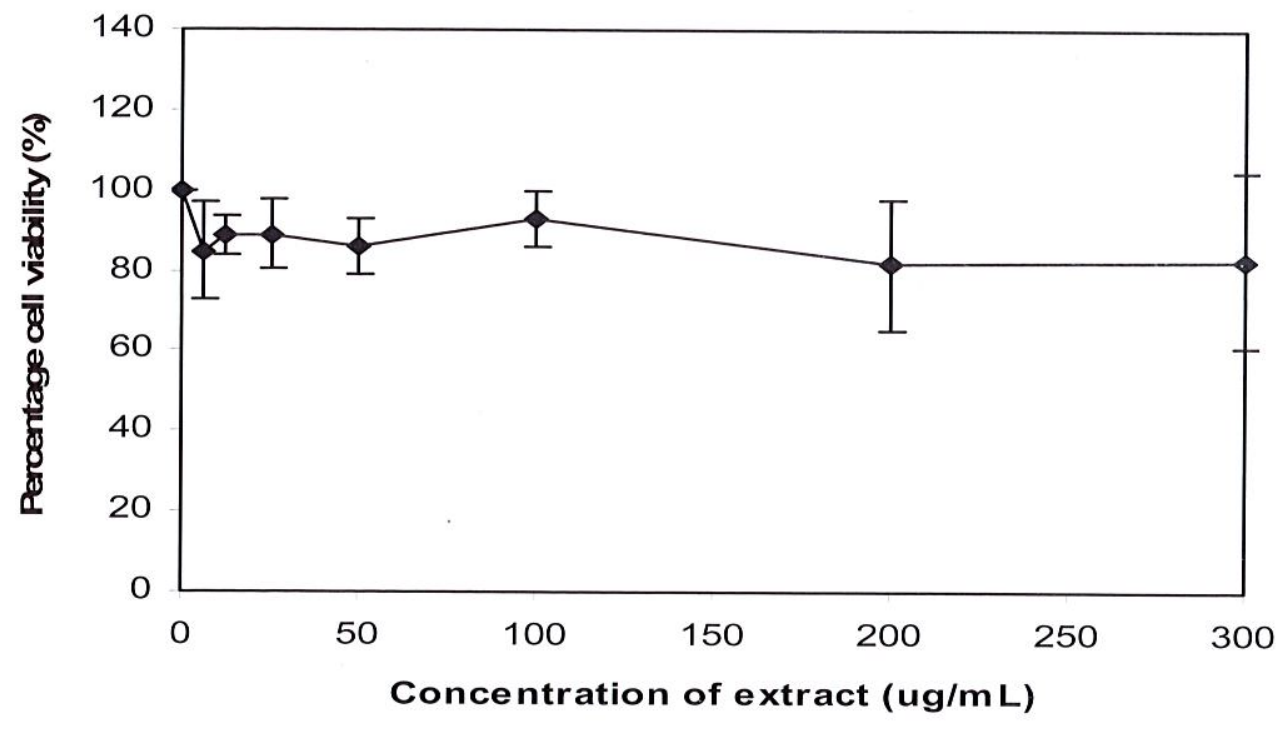

Figure 3(d): Percentage of cell viability of NIH/3T3 cells cultured in media containing 10\% FBS in the presence of varying concentrations of the hexane extract of Euphorbia hirta. 


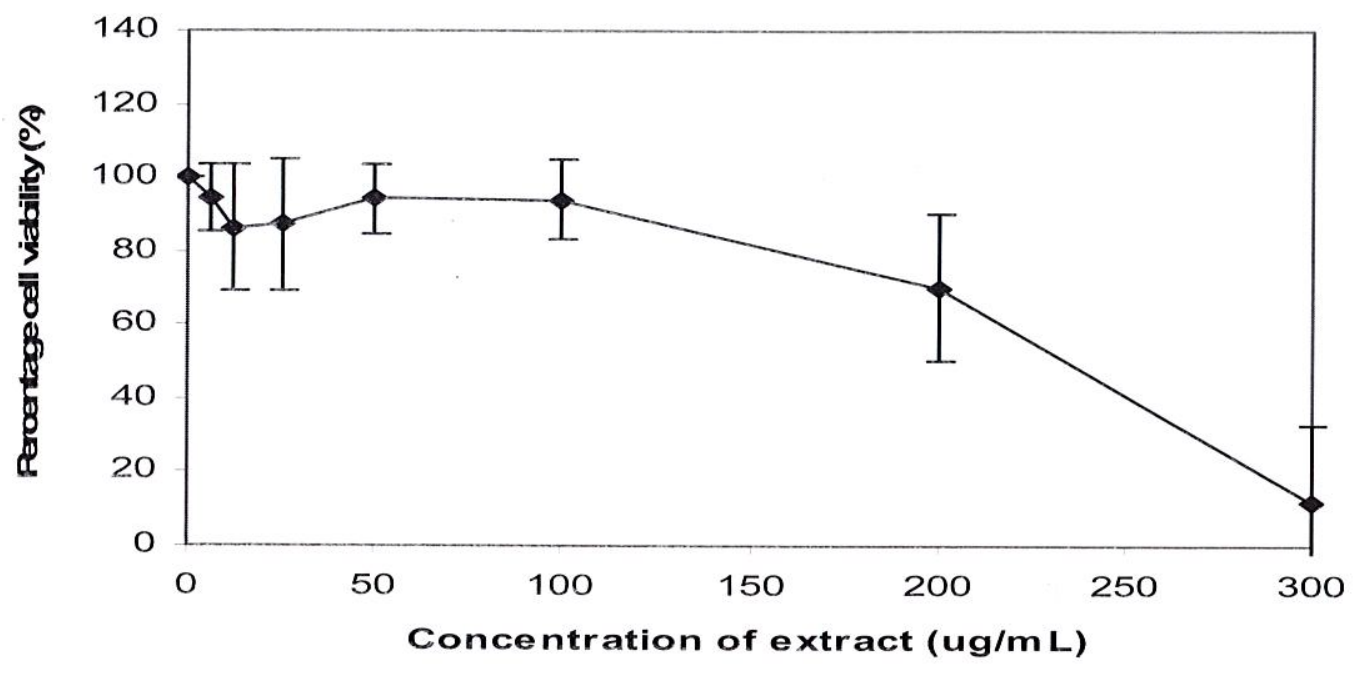

Figure 4: The results (s.e.m. \pm s.e.) showed the response of guinea pig ileum to histamine. Histamine alone (solid square), $\mathrm{n}=5$. In the presence of $5 \mathrm{mg} / \mathrm{mL}$ of aqueous extract of Euphorbia hirta (solid circle), $\mathrm{n}=4$. In the presence of $10 \mathrm{mg} / \mathrm{mL}$ of aqueous extract of Euphorbia hirta (solid triangle), $\mathrm{n}=5$

\section{ACKNOWLEDGEMENTS}

The study was supported by IMU research grants, 049/2004 and 042/2004.

\section{REFERENCES}

1. Johnson, L.L., Dyer, R. and Hupe, D.J. (1998). Matrix metalloproteinases. Current Opinion in Chemical Biology 2: 446-71.

2. Vijaya, K., Ananthan, S. and Nalini, R. (1995). Antibacterial of theaflavin, polyphenon 60, (Camellia sinensis) and Euphorbia hirta on Shigella spp. - a cell culture study. J. Ethnopharmacology 49: 115-8.

3. Hore, S.K., Ahuja, V., Mehta, G., Kumar, P., Pandey, S.K. and Ahmad, A.H. (2006). Effect of aqueous Euphorbia hirta leaf extract on gastrointestinal motility. Fitoterapia 77: 35-8.

4. Tona, L., Ngimbi, N.P., Tsakala, M., Mesia, K., Cimanga, K., Apers, S., De Bruyne, T., Pieters, L., Totte, J. and Vlietinck, A.J. (1999). Antimalarial activity of 20 crude extracts from nine African medicinal plants used in Kinshasa, Congo. J. Ethnopharmacology 68: 193-203.

5. Burkill, I.H. (1966). A dictionary of the economic products of the Malay Peninsular. 2nd edn. Ministry of Agriculture.

6. Re, R., Pellegrini, N., Proteggente, A., Pannala, A., Yang, M. and Rice-Evans, C. (1999).
Antioxidant activity applying an improved ABTS radical cation decolorization assay. Free Radical Biology \& Medicine. 26: 1231-1237.

7. Geran, R.I., Greenberg, N.H., Macdonald, M.M., Schumacher, A.M. and Abbott, B.J. (1971). Protocols for screening chemical agents and natural products against animal tumours and other biological systems. Canada Chemotherapy Report 12: 59-61.

8. Prior, R.L. and Cao, G. (1999). Antioxidant capacity and polyphenolic components of teas: Implications for altering in vivo antioxidant status. Proceedings of the Society for Experimental Biology and Medicine 220(4): 25561.

9. Tona, L., Cimanga ,R.K., Mesia, K., Musuamba, C.T., De Bryune, T., Apers, S., Hernans, N., Van Miert, S., Pieters, L., Totte, J. and Vlietinck, A.J. (2004). In vitro antiplasmodial activity of extracts and fractions from seven medicinal plants used in the Democratic Republic of Congo. J. Ethnopharmacology 93: 27-32

10. Lanhers, M.C., Fleurentin, J., Dorfman, P., Mortier, F. and Pelt, J.M. (1990). Analgesic, antipyretic, and anti-inflammatory properties of Euphorbia hirta. Planta Medica 57(3): 225-31.

11. Ogasawara, H., Fujitani, T., Drzewiecki, G. and Middleton, Jr. E. (1986). The role of hydrogen peroxide in basophil histamine release and the effect of selected flavonoids. J. Allergy and Clinical Immunology 78: 321-328 